\section{Survey of trainees' education and training 1987}

DeAR Sirs

From its inception our College has made a great effort to improve standards of training and teaching by means of its approval visits and by its membership of the Joint Committee for Higher Psychiatric Training. Shortly before the College was established its predecessor, the Royal Medico Psychological Association, commissioned me to conduct a survey into the state of postgraduate education in psychiatry, and as part of this I interviewed trainees in three regions. The results of this survey were published in an RMPA special publication: ${ }^{1}$ I would like to think that the survey's findings and the recommendations arising from them helped form the standards of approval visits, at least in the earlier years of the College.

There is no doubt that there have been major improvements since the initial enquiry and I would like to update my findings by means of a new survey directed at trainees in the three areas that were visited in 1971, specifically the SouthEast Thames, Oxford and North-Western regions. I would hope that the survey would indicate what progress had been made, but in addition would indicate those areas of training where further improvements need to be implemented.

The enquiry, which has received the support of the College, is being directed at all trainees, senior and junior, working in the three regions, but excluding doctors in a GP vocational training scheme, locums appointed for less than three months and SHOs in the first three months of their first psychiatric appointment.

The enquiry is strictly confidential and anonymous but questionnaires will be identified by an index number so that we can send reminder letters as appropriate. The key will be held by Jane Boyce of the College's Education Department and myself in order to preserve clinical anonymity and confidentiality. In the final analysis hospitals will not be identified although the three regions will.

I hope to be sending out these questionnaires to trainees early in May. You will appreciate that I am hoping for as high a response rate as possible. I will also be asking consultants in hospitals in the three regions to fill in a very brief form about their training activities. Early this year I also propose to send out to consultants in general psychiatry appointed for the first time between 1 October 1984 and 30 September 1986, a questionnaire relating to the training that they have received before their consultant appointment. This is not a new venture, the last set of results being published in the Bulletin in January $1984 .^{2}$

Fulbourn Hospital,

Peter Brook Cambridge

\section{REFERENCES}

'Brook, P. (1973) Psychiatrists in training. The Report of the Royal Medico Psychological Association's Manpower and Education Project: British Journal of Psychiairy, Special Publication No. 7.

${ }^{2}$ Brook, P. (1984) Consultant psychiatrists: their career choice and training. Bulletin of the Royal College of Psychiatrists, 8, 2-5.
Alternative reading list

\section{DeAr Sirs}

The late Professor Pond, lecturing at University College Hospital in the far-off fifties, used to say that one could learn as much psychiatry from good literature as from the textbooks (though I know he did not mean us to be ignorant of the latter). With that in mind, I later produced an extracurricular reading list for trainees in Chicago and a modified version of it now is in the 'kit' of miscellaneous reading material we give to newly-arrived trainees on our Unit.

Sheffield psychiatry has been 'sectorised' since 1 April 1986 and in the discussions leading up to that Big Bang it was generally agreed that different sectors would develop their own 'styles' as time went on. Readers may be interested to compare our list with that of Dr Gill and Dr Spear (Bulletin, October 1986, 10, 284), who operate somewhat to the North and West of our sector; we are obviously rather lower-browed down our way, but to make up for that our list is furnished with an introductory Apologia:

This short reading list is intended to convey a point, not to cover a syllabus. The point is that there is more to understanding people than is embraced by the formal study of psychology or psychopathology. No-one who loves gardening will settle for plastic flowers in his house; and who would exchange the sight of a falcon in the wild for a stuffed owl in a glass case? If you are not convinced, read The Collector; then read on.

Anyone who works with people-and who does not?needs a broad and appreciative comprehension of human nature and its endless variety. This kind of wisdom is not to be acquired by merely learning a series of academic facts or theories about disorders of the mind. If one is ever to bring help to another human being in distress, one must learn how to see the world through another person's eyes. This requires the imagination to conceive of a viewpoint different from one's own-a set of preconceptions and values so different, sometimes, as to seem bizarre or alarming.

People differ in the extent to which they show this kind of imagination. Sometimes it is the fear of perceiving oneself and one's own situation too clearly which inhibits one's empathy for others; but often simple lack of experience, lack of opportunity to appreciate the diversity of human experience, makes one too limited or too cautious in speculating as to what someone may mean by this or that ambiguous remark, what their undisclosed feelings, beliefs and intentions may be. Well written novels, well read, increase one's imaginative range. As Bacon said, 'reading maketh a full man'-as opposed to an empty one.

Our hope is that these books may show some readers (if they have not already discovered this for themselves) how to profit from the special gift which a writer offers to Society: his ability to participate imaginatively in the lives of others and to communicate the resulting insight in words. Most of the books are fiction; but I have included some autobiography because all fiction is partly autobiographical and autobiography is a special kind of fiction. The auto- 
biographer, like any other reflective person, sees in his own life a pattern, a structure and a meaning which he interprets as best he may; in publishing his life he invites the reader to accept or to disagree with that interpretation. He puts his life in your hands.

A few of the books depart completely from the narrative style to which we are ordinarily accustomed. They follow a trend typified, I suppose, by Gertrude Stein when she began to experiment with 'automatic writing', using a technique akin to autohypnosis so as to reveal levels of her own mind not easily accessible by ordinary means. In writings of this kind the manner is as important as the matter. A definite act of submission is required of the reader, if the text is to succeed in producing in him the state of mind which it is capable of communicating. Learn to read Beckett and Robbe-Grillet and you have learned something about listening to certain types of person. Learn this lesson from exotic authors such as these and you are ready to apply it every day; for in every form of human communication the style reveals the author; and reading what is ambiguous or equivocal is a good training for listening to what the other person means but does not say.

\section{Fiction}

Under the Net (Iris Murdoch); The Catcher in the Rye (J. D. Salinger); The Collector and The Magus (John Fowles); A Kiss Before Dying (Ira Levin); This Sweet Sickness (Patricia Highsmith); The Dharma Bums (Jack Kerouac); Lolita and Laughter in the Dark (Vladimir Nabokov); The Heart of the Matter and Brighton Rock (Graham Greene); The Detective (Roderick Thorp); The Double. The Idiot and Crime and Punishment (Feodor Dostoievski); The Sot-Weed Factor (John Barth); The Crescent Moon (Francis Brett Young); Sirius (Olaf Stapledon); The Rains Came (Louis Bromfield); The History of Mr Polly (H. G. Wells); The Genius and the Goddess (Aldous Huxley); The Good Earth (Pearl S. Buck); The Stars Look Down (A. J. Cronin); The Judge's Story (Charles Morgan); The Castle and The Trial (Franz Kafka); The Black Sheep (Rudyard Kipling); Mister Johnson (Joyce Cary); A Man of Forty (Gerald Bullett); Invitation to the Waltz (Rosamund Lehmann); Darkness at Noon (Arthur Koestler); Of Human Bondage (Somerset Maugham); A Madman's Defence (A. Strindberg).

\section{Autobiography}

Growing-This relates to the second period of the author's life but I suggest reading it before Sowing, which deals with his childhood-(Leonard Woolf); Sinister Street (Compton Mackenzie); Journal of a Disappointed Man (W. N. P. Barbellion); A Mathematician's Apology (G. H. Hardy, Cambridge University Press, 1967).

\section{Exotica}

Murphy and Molloy (Samuel Beckett); La Maison de Rendezvous (Alan Robbe-Gillet, English translation, New York: Grove Press, 1966).

\section{Essays}

In Peacock's Selected English Essays (World's Classics, London: Oxford University Press); Recollections of Childhood (Richard Steele); Of Studies (Francis Bacon); On the Ignorance of the Learned and On Familiar Style (William Hazlitt).

Middlewood Hospital

Hugh B. G. ThOMas Sheffield

\section{DeAr SIRS}

I have read with interest two letters in the Bulletin (February 1985 and October 1986) by Drs Culliford and Murphy and Drs Gill and Spear respectively on the use of novels in the study of psychiatry. As a retired social work teacher I am venturing to write and say that for a number of years I gave a course to social work students on the use of creative literature as an adjunct to the study of psychology and sociology in understanding human behaviour. The bibliography was divided into sections (childhood, marriage, mental illness etc). I think that in any bibliography compiled by psychiatrists this idea might be useful, e.g. in a study of mental illness Sylvia Plath's The Bell Jar, Hannah Green's I Never Promised You a Rose Garden and Scott Fitzgerald's Tender is the Night are good examples; in regard to marriage Sinclair Lewis' Dodsworth and Edward Albee's play Who's Afraid of Virginia Woolf provide excellent material. Students could also not do better than to read John Clare's poem Written in Northampton County Asylum written well over 100 years ago, in which one line "I am the self-consumer of my woes" would certainly provide an essay title.

For any of your readers who are interested I have also prepared a bibliography on Third World literature (particularly African literature) which mirrors behaviour in social change and I would be pleased to send a copy to anyone who wishes it on receipt of $£ 1$ to cover photocopying and postage.

\section{Ffynone Close}

Elizabeth Clarkson

\section{Swansea SAI 6DA}

\section{DeAr SIRS}

I have been wondering how I would react to the patient (or trainee psychiatrist) who confessed to recent reading of the books recommended by Drs Gill and Spear (Bulletin. October 1986, 10, 284).

I should certainly feel compelled to delve into the remarkable predilection for books set in imaginary fantasy worlds $(25 \%)$, and involving science fiction or the supernatural (17\%). I suppose having most of the authors dead (66\%) could be accepted as normal.

I should be a little concerned about the psychopathology suggested by The Collector and The Story of $O$, and the lack of veracity suggested by a claim to have read Finnegan's Wake.

2 Copeland Drive

Peter Birkett

Suffern, New York, USA 